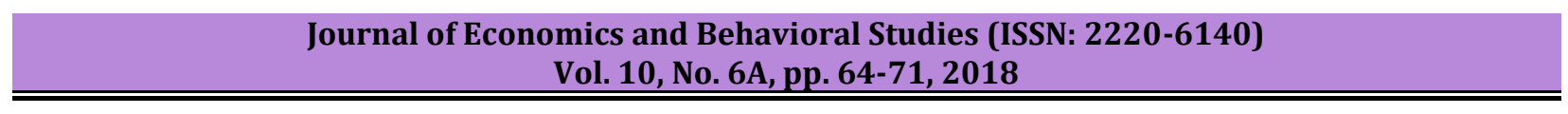

\title{
The Use of Modern Technology for Rural Industrialization and Its Implications on the Rural SMEs Economic Growth
}

\author{
Lawrence Mpele LEKHANYA \\ Durban University of Technology, Department of Public Management and Economics, South Africa \\ lawrencel@dut.ac.za
}

\begin{abstract}
Hence technology delivery is perceived to be an essential catalyst for rural development. This paper intends to present an empirical study on the use of modern technology for rural industrialization and its theoretical and practical implication on the rural SMEs economic growth. The idea of rural industrialization and how it can enhance the rural SMEs economic growth still the issue of concern of many policy-makers. The study seeks to establish understanding, knowledge and awareness about how the use of modern technology would assist in building strong rural industrialization that will have a positive change in the rural SMEs economy. In this research 127 participants consist with business managers/owners running SMEs in the province of KwaZulu-Natal were chosen for empirical data collection from both South and Northern parts of the Province. SPSS (24.0) version was used for the analysis of data. A quantitative questionnaire was used and distributed to the respondents. The findings revealed that in many cases there is no specific rural industrialization policy does not exist or somehow fall short, government attitudes towards rural industrialization as well as rural infrastructure development were also identified by respondents as areas of concern for rural industrialization. The exploratory and quantitative nature limited the survey. Hence, the application of this result should be made with utmost care. Further investigation which may include large and other parts of the country is therefore recommended.
\end{abstract}

Keywords: Industrialization; Rural SMEs; Implications; Modern Technology; Economic growth.

\section{Introduction}

In many parts of the world business entities are now looking to get almost every essential goods/service they need out the city centres, these include large part South Asia, China, Indonesia, Thailand and Vietnam (Hartley 2015). China rural enterprises regarded as a classic example that contributes to economic growth, institutional transformation and rural development. It is believed that the huge participation in rural industrialization by rural people come from the diversified industrialization over a quarter century (Kumar, 2017). However, the inceptions of new modern technology have changed the way businesses have been operating, in many cases business environment has drastically changed and improved for the better (Lekhanya, 2014). The use of modern technology perceived to be more important for the modernizing the agribusiness production and diversifying SMEs rural products (Gandhi, 2014). Since many decades ago, various factor such as capital and access to the relevant information by the start-ups business managers or owners found hindering the establishment and the growth of many business entities (Ramey, 2012). It is very critical for the authorities and policy-makers to create an enabling business environment including providing programs, national policies intended to assist with the required knowledge and entrepreneurial skills, technology database, technological capacity building as well as business research and development (SMEs report, 2017). SMEs regarded as a vital sector for the innovation and adoption of a new wave of technology, while on the hand they can also grow during the process (Michael, Aggarwal, Kennedy., Wenstrup., Rüßmann., Ruba, Chen and Bezerra, 2013). There is a need to think deeply on the kind of technology that can be sustained in future (Dhar, 2017). Schilling and Chiang (2009) believe that there is a need for modern technology that will transform an economy and make use of depletion of a non-renewable resource to make a substantial influence for the development of an economy that will benefit the next generations. They maintain that the depletion of non-renewable resources which form the backbone of modern technology is a serious environmental impact and social arising from increasing inequity reflected as one of the most causes of poverty and isolation of societies.

Problem Statement: The rural industrialization development that often brought by the local entrepreneurs has been overlooked (Bar-El \& Fleckenstein, 1990). Subsequently, rural places viewed as less industrial development with small markets for by many potential entrepreneurs as compared to urban areas. Therefore, rural industrial needs the mobilization of resources in order to be attractive and well developed for business. 
According to Patel1 \& Chavda (2013), some of the challenges facing the majority of rural entrepreneurs comprise limited technical knowledge and skills, financial constraints, entrepreneurial education background, business management abilities and marketing skills, all these are due to the lack of basic services essential for the business operations in particular rural place in the developing countries, thus, make it impossible for the rural industries to take establish and expand. Although in recent years, rural entrepreneurs begin to see potential growth in the rural and semi-urban areas stifled economic development and lack of product technologies affected the development of rural communities and left them still living in the dire environment (Chigumbu, 2018). Mpofu \& Watkins-Mathys (2011) state that the business organizations operating from underdeveloped and remote areas in South Africa are continuously struggling technologically, this makes it difficult for them to compete and expand in a marketplace where there is highly geared to ICT innovations. Hence, there are few brilliant examples of countries which have managed to help their local nationals to develop their businesses online using various tools such as digital media, social networks and Facebook, tweet and Instagram, WhatsApp and snapchat (Vassilakopoulou, 2013). Werngren (2013) states that SMEs more often are hesitant to use modern technologies due to the lack of expertise and lack of qualified personnel who can manage properly. He believes that utilization of new technology can help SMEs to penetrate local, regional and international markets while embracing the best business practice. Therefore, these make it difficult for rural Industrialization to use modern technology.

\section{Aims and Objectives}

Aims: Primary purpose of this article publication is to outline critical challenges for the use of modern technology for the rural industrialization of SMEs economic growth.

\section{Objectives}

- To examine the level of understanding and knowledge of the use of modern technology for the rural industrialization of SMEs economic growth;

- To identify factors affecting the use of modern technology for rural industrialization of SMEs economic growth;

- To discuss the implications of the use of modern technology on the rural industrialization of SMEs economic growth; and

- To make recommendations on what should be done to encourage the use of modern technology to achieve much need rural industrialization of SMEs economic growth.

\section{Literature Review}

Definition of Rural Industrialization: Cloke (1985) mentioned variation, dynamics and functions as the main reasons making it perceived to be very hard to describe rurality. The technological, economic and social developments in the rural places are caused by many non-quantitative issues prevailing in the in many rural environments and impacting on rural livelihood (Long, Zou \& Liu, 2009). Industries diversification in a rural location and how the business operations are conducted described as rural industrialization. However, small and large units found away from urban places or intended to move units away from urban to rural places defined as rural industrialization (Sundar \& Srinivasan, 2009). Furthermore, the concept of developing villages through the introduction of business industries, modernizing economic growth, increasing social innovation, encouraging the adoption and the use of new technologies for business gains and job creation opportunities, increasing rural household incoming and changing rural social buying power and consumer behavior also called rural industrialization (Chapter-I, 2017). Rural industrialization aimed to develop, promote, provide balance and decentralize economy of the country. Its main purpose is to an enable industrial growth, reduction of unemployment, the removal inequality of economic distribution, rural poverty eradication and rural and urban integrated development (the economic weekly, 1960)

Benefits of Rural Industrialization: The industrialization provides growth of industries in the designated places such as rural areas. This concept includes bringing alternative services/goods close to the local communities, therefore, in many cases rural people will have different products to choose from, people will be able to get types of public and private transport which can make it possible for them to get their products in the market very easily and quick. Rural communities benefit in get cheaper rates due to the large scale of production of goods. Industrialization helps in the economic growth and economic development various 
economic activities such as trade agriculture transport and entrepreneurship improve and grow national economy. According to Sehgal (2015), industrialization plays a major role for the national economic development. However, it has been noticed that good industrial policy framework assists in the essential recommendations for industrial development meant to advance industrial competitiveness focusing more on the SMEs. Khan (2009) maintains that industrial policy framework helps in exposing local SMEs with international markets. Utilization of resources is become very easy and effective through industrialization by different people from different backgrounds, short of skills in specialist sectors like manufacturing industry and technology business can be easily addressed (Mwalenga, 2012).

The Significance of Technology on Rural Industrialization: According Jayadatta (2017), deficiency of technical know-how is the challenge for many rural entrepreneurs he further mentioned that facilities for training requirements and more relevant services create a huge impact of the entrepreneurship development in the rural places. This premise supported by Patel \& Chavda (2013) indicating that in India, education system faced with job industry challenge and online entrepreneurship. These, however, believed that they can be overcome by using modern technology effectively and embracing the ideal of it. Lele (2017) stress that in today's world, modern technologies have capabilities of changing agriculture structural transformation taking it to the high level of productivity and speeding manufacturing of various goods and help the economy acceleration growth, while also it helps to transform individual and improves lives of people in the developing countries. It is recognized worldwide that science and technology are among the most powerful motive forces to bring about dynamic changes in the society; and that appropriate and wise application of science and technology to all facets related to human welfare can bring about desired social and economic transformation (Rai \& Kumar, 2012).

The Use of Modern Technology for Rural Industrialization: Jayadatta (2017) state that the use of modern technology is not frequently common as a source for business information. Rural entrepreneurs are common to rely on social links and family and personal relationships to spread awareness regarding the business, even though somewhere and somehow these might have a negative stimulus to the business itself. According to Saxena (2012), these are due to the lack of technical knowledge and lack of training facilities experienced by rural entrepreneurs. Manimala et al. (2012) indicate local politics and willing of the relevant authorities and policy-makers could have an impact on the business abilities to adopt and make use of modern technology and affect the growth of the business. (Vitez, 2017) believe that SMEs are getting much need technology boost to compete with big business for the potential markets. Skinner \& Goodier (2016) mentioned limited of lack of information and understanding of the important part played by ICT and its significant role in the adoption and the use of technology by the small business entrepreneurs.

\section{Research Methodology used for the Survey}

Different rural areas were selected to conduct this survey in southern and northern regions of KZN province. Empirical data were collected from 127 business owners/managers. Closed-ended questionnaire formulated from the literature review was distributed with the aid of research assistants to the targeted businesses premises. SPSS (Statistical Package for the Social Sciences) Version 24.0 was used for data collection and later results were presented in the table formats as indicated below.

Table 1: The Sample Profile Used

\begin{tabular}{lll}
\hline Cluster/area & Frequency & Percent \\
\hline Harding (uMuziwabantu), & 34 & 27 \\
Ixopo (Ubuhlebezwe) & 16 & 13 \\
Underberg (Sisonke) & 19 & 15 \\
Umzimkhulu & 24 & 19 \\
Zingolweni & 34 & 27 \\
\hline
\end{tabular}

Table 1 presents the cluster/area of participants' business and how many they were per cluster. Since the measuring instruments for this study were closed-ended questionnaire. The following Table 2 shows the summary of key questions. 
Table 2: Summary of Key Questions

\begin{tabular}{|c|c|}
\hline Research area & Questions \\
\hline $\begin{array}{l}\text { Rural industrialization policy } \\
\text { development }\end{array}$ & $\begin{array}{l}\text { Lack of Policy development on rural industrialization has negative } \\
\text { influence: } \\
\text { Alternative response: } 5 \text { Likert }\end{array}$ \\
\hline $\begin{array}{l}\text { Rural Infrastructure for } \\
\text { industrialization }\end{array}$ & $\begin{array}{l}\text { Poor infrastructure has a negative impact on rural industrialization: } \\
\text { Alternative response: } 5 \text { Likert }\end{array}$ \\
\hline Rural socio-economic development & $\begin{array}{l}\text { Shortage of socio-economic development has an influence on the rural } \\
\text { industrialization: } \\
\text { Alternative response: } 5 \text { Likert }\end{array}$ \\
\hline $\begin{array}{l}\text { Government attitude for rural } \\
\text { industrialization }\end{array}$ & $\begin{array}{l}\text { Government attitude towards the rural industrialization has much } \\
\text { influence: } \\
\text { Alternative response: } 5 \text { Likert }\end{array}$ \\
\hline $\begin{array}{l}\text { Rural market for potential } \\
\text { industrialization } \\
\text { State resources for rural } \\
\text { industrialization development }\end{array}$ & $\begin{array}{l}\text { Size of the rural market has the impact of rural industrialization: } \\
\text { Alternative response: } 5 \text { Likert } \\
\text { Availability of state resources has an influence on the rural } \\
\text { industrialization development: } \\
\text { Alternative response: }\end{array}$ \\
\hline $\begin{array}{l}\text { Technological development for rural } \\
\text { industrialization }\end{array}$ & $\begin{array}{l}\text { Poor technological development has an influence on the rural } \\
\text { industrialization: } \\
\text { Alternative response: } 5 \text { Likert }\end{array}$ \\
\hline
\end{tabular}

Factors Affecting the Rural Industrialization: In recent times, in many developing countries incubator movements initiated by technology development (AL-Mubaraki \& Aruna, 2013). The shortage of employment opportunities in rural areas has caused difficulties including low income and less rural business uptake and the situation forced people living the rural villages to immigrate to the cities (Shahabi, Salehi \& Seifolahi, 2015). The supply of raw materials makes it difficult for the rural industrialization (Long, Zou \& Liu, 2009). Dinkelman (2010) believes that the state of rural electrification affected the rural business development and creation of employment rural women as well as rural migration behavior.

\section{Findings}

The previous section has outlined comprehensive literature reviewed on the challenges faced rural SMEs on the use of modern technology for rural industrialization. The focus of this section is explained the key findings from the empirical data collected. Response was received from $127(n=127)$ participants operating enterprises in KZN province.

Table 3:

\begin{tabular}{|c|c|c|c|c|c|c|c|}
\hline \multirow{2}{*}{$\begin{array}{l}\text { Research area } \\
\text { Rural } \\
\text { Industrialization } \\
\text { policy } \\
\text { development }\end{array}$} & & agreed & Neutral & disagreed & $\mathbf{X}$ & df & $\mathbf{P}$ \\
\hline & $\begin{array}{l}\text { environmental } \\
\text { regulation } \\
\text { requirements }\end{array}$ & $\begin{array}{l}66 \\
(52 \%)\end{array}$ & $\begin{array}{l}28 \\
(22 \%)\end{array}$ & $28(26 \%)$ & $\begin{array}{l}\mathrm{X}^{2} \\
=.709\end{array}$ & $\mathrm{df}=1.11095$ & $P=.000$ \\
\hline & public & & & & & & \\
\hline & $\begin{array}{l}\text { procurement } \\
\text { regulations }\end{array}$ & $\begin{array}{l}61 \\
(56 \%)\end{array}$ & $\begin{array}{l}29 \\
(23 \%)\end{array}$ & $27(23 \%)$ & $X^{2}=.666$ & $\mathrm{df}=1.15503$ & $\mathrm{P}=.000$ \\
\hline & tough & & & $26(12 \%)$ & & $\mathrm{df}=1.09435$ & $\mathrm{P}=.000$ \\
\hline & $\begin{array}{l}\text { government } \\
\text { regulations and } \\
\text { requirements }\end{array}$ & $\begin{array}{l}82 \\
(72 \%)\end{array}$ & $\begin{array}{l}19 \\
(15 \%)\end{array}$ & & $\begin{array}{ll}\mathrm{X}^{2} & = \\
.641\end{array}$ & & \\
\hline
\end{tabular}

A large number of participants for example 66 (52 percent) agreed with the statement that environmental regulation requirements still fund to be stamping block for the easy adoption of modern technology for the rural industrialization. While at the same time, the considerable number 28 ( 22 percent) of the respondents 
remain neutral, when 28 (26 percent) disagree with the statement. Statistical test done on this variable indicates that $(\mathrm{x} 2=.709 ; \mathrm{DF}=1.11095 ; \mathrm{p}=.000)$ significant. More numbers of respondents, 61 (56 percent) agree with the statement, about 29 (23 percent) were neutral, while 27(23 percent) disagree with the statement that public procurement regulations have the impact of the use of modern technology for the rural industrialization. Statistical test done on this variable indicates that $(x 2=.666 ; D F=1.15503 ; p=.000)$ significant. Majority of the respondents, 82 (72 percent) agree with the statement that tough government regulations and requirements have an influence on the use of modern technology for the rural industrialization.

Table 4:

\begin{tabular}{|c|c|c|c|c|c|c|c|}
\hline Research area & & Agreed & Neutral & Disagree & $\mathbf{X}$ & df & $\mathbf{P}$ \\
\hline $\begin{array}{l}\text { Rural } \\
\text { Infrastructure for } \\
\text { industrialization }\end{array}$ & $\begin{array}{l}\text { poor quality } \\
\text { equipment }\end{array}$ & $\begin{array}{l}71 \\
(56 \%)\end{array}$ & $\begin{array}{l}24 \\
(19 \%)\end{array}$ & $32(26 \%)$ & $X 2=.764$ & $\mathrm{df}=1.15621$ & $\mathrm{P}=.000$ \\
\hline
\end{tabular}

The results reveal that, 71 (56 percent) agreed, while a small number of respondents, 24 (19 percent) remain neutral, 32(26 percent) disagree with the statement that poor quality of equipment or rather infrastructure have an impact on using the modern technology for the rural industrialization. Statistical test done on this variable indicates that $(\mathrm{x} 2=.764 ; \mathrm{DF}=1.15621 ; \mathrm{p}=.000)$.

Table 5:

\begin{tabular}{|c|c|c|c|c|c|c|c|}
\hline Research area & & Agreed & Neutral & Disagreed & $\mathbf{X}$ & df & $\mathbf{P}$ \\
\hline \multirow[t]{3}{*}{$\begin{array}{l}\text { Rural socio- } \\
\text { economic } \\
\text { development }\end{array}$} & $\begin{array}{l}\text { late payments } \\
\text { from ordinary } \\
\text { customers }\end{array}$ & $\begin{array}{l}78 \\
(62 \%)\end{array}$ & $\begin{array}{l}22 \\
(17 \%)\end{array}$ & $27(22 \%)$ & $X 2=.678$ & $\mathrm{df}=1.20652$ & $\mathrm{P}=.000$ \\
\hline & $\begin{array}{l}\text { lack of support } \\
\text { from friends and } \\
\text { family affects }\end{array}$ & $\begin{array}{l}53 \\
(42 \%)\end{array}$ & $\begin{array}{l}41 \\
(32 \%)\end{array}$ & $33(27 \%)$ & $X 2=.696$ & $\mathrm{df}=1.23988$ & $\mathrm{P}=.000$ \\
\hline & $\begin{array}{l}\text { lack of support } \\
\text { from business } \\
\text { consultancy } \\
\text { services }\end{array}$ & $\begin{array}{l}81 \\
(64 \%)\end{array}$ & $\begin{array}{l}18 \\
(14 \%)\end{array}$ & $27(23 \%)$ & $X 2=.695$ & $\mathrm{df}=1.24411$ & $\mathrm{P}=.000$ \\
\hline
\end{tabular}

The study found that most participants, 78 (62 percent) agreed with the statement that late payment from ordinary customers has an influence on the use of modern technology for rural industrialization. About 22 (17 percent) of the participants remain neutral, while just $27(22$ percent) disagree with the statement. Statistical test done on this variable indicates that $(\mathrm{x} 2=.678 ; \mathrm{DF}=1.20652 ; \mathrm{p}=.000) .53(42$ percent $)$ agreed with the statement that lack of support from friends and families affects the use of modern technology for the rural industrialization. When $41(32$ percent) of the respondents were neutral, 33(27 percent) of the respondents disagree. Statistical test done on this variable indicates that $(x 2=.696 ; \mathrm{DF}=1.23988 ; \mathrm{p}=.000)$. Lack of support from business consultancy services confirmed by 81 (64 percent) of respondents that have an impact on the use of modern technology for rural industrialization. 18(14 percent) were neutral and 27(23 percent) of the respondents disagree. Statistical test done on this variable indicates that $(\mathrm{x} 2=.695$; $\mathrm{DF}=1.24411 ; \mathrm{p}=.000)$.

Table 6:

\begin{tabular}{|c|c|c|c|c|c|c|c|}
\hline Research area & & Agreed & Neutral & Disagree & $\mathbf{X}$ & df & $\mathbf{P}$ \\
\hline \multirow[t]{2}{*}{$\begin{array}{l}\text { Government } \\
\text { attitude for rural } \\
\text { industrialization }\end{array}$} & $\begin{array}{l}\text { payments from } \\
\text { government }\end{array}$ & $\begin{array}{l}86 \\
(60 \%)\end{array}$ & $\begin{array}{l}21 \\
(17 \%)\end{array}$ & $28(24 \%)$ & $X 2=.689$ & $\mathrm{df}=1.21843$ & $\mathrm{P}=.000$ \\
\hline & $\begin{array}{l}\text { high levels of } \\
\text { domestic } \\
\text { taxation }\end{array}$ & $\begin{array}{l}94 \\
(74 \%)\end{array}$ & $\begin{array}{l}19 \\
(15 \%)\end{array}$ & 7 (7\%) & $X 2=.595$ & $\mathrm{df}=1.12604$ & $\mathrm{P}=.000$ \\
\hline
\end{tabular}


The results reveal that $86(60$ percent) agreed, while 21 (17 percent) remain neutral and with 28 (24 percent) of the respondents disagree with that payment from government affects the use of modern technology. Statistical test done on this variable indicates that $(\mathrm{x} 2=.689 ; \mathrm{DF}=1.2843 ; \mathrm{p}=.000)$. High levels of domestic taxation indicated by 94 (74 percent) of the respondents as a major influence in used modern technology for rural industrialization. 19 (15 percent) of respondents remain neutral and very few 7(7 percent) disagreed. Statistical test done on this variable indicates that $(\mathrm{x} 2=.595 ; \mathrm{DF}=1.12604 ; \mathrm{p}=.000)$.

Table 7:

\begin{tabular}{|c|c|c|c|c|c|c|c|c|}
\hline \multirow{4}{*}{$\begin{array}{l}\text { Research area } \\
\text { Rural market } \\
\text { for potential } \\
\text { industrialization }\end{array}$} & & Agreed & Neutral & Disagreed & $\mathbf{X}$ & & Df & $\mathbf{P}$ \\
\hline & $\begin{array}{l}\text { selling } \\
\text { similar } \\
\text { products }\end{array}$ & $\begin{array}{l}86 \\
(68 \%)\end{array}$ & $\begin{array}{l}23 \\
(18 \%)\end{array}$ & $12(14 \%)$ & $\begin{array}{l}X 2 \\
.615\end{array}$ & $=$ & $\mathrm{df}=1.654$ & $\mathrm{P}=.000$ \\
\hline & $\begin{array}{l}\text { weak domestic } \\
\text { demand }\end{array}$ & $\begin{array}{l}78 \\
(72 \%)\end{array}$ & $\begin{array}{l}26 \\
(21 \%)\end{array}$ & 17 (17\%) & $\begin{array}{l}X 2 \\
.590\end{array}$ & $=$ & $\mathrm{df}=1.19434$ & $P=.000$ \\
\hline & $\begin{array}{l}\text { access } \\
\text { materials }\end{array}$ & $\begin{array}{l}58 \\
(46 \%)\end{array}$ & $\begin{array}{l}29 \\
(23 \%)\end{array}$ & 38 (31\%) & $\begin{array}{l}\mathrm{X} 2 \\
.595\end{array}$ & $=$ & $\mathrm{df}=.01636$ & $P=.000$ \\
\hline
\end{tabular}

86(68 percent) of the respondent agreed with the statement that selling of similar products has an influence on the use of modern technology for rural industrialization, while 23 (18 percent) stay neutral. Very few numbers of the respondents 12 (14 percent) disagreed with the statement. Statistical test done on this variable indicates that $(x 2=.615 ; \mathrm{DF}=1.654 ; \mathrm{p}=.000)$. Weak domestic demand indicated by 78 (72 percent) of the respondents that do have an impact on the use of modern technology for the rural industrialization. With 26(21 percent) of the respondents remains neutral and 17 (17 percent) disagreed with the statement. Statistical test done on this variable indicates that $(x 2=.590 ; D F=1.9434 ; p=.000)$. 58(46 percent) of the respondents agreed that access to raw materials does have an influence on the use of the modern technology for rural industrialization. 29(23 percent) of the respondents remain neutral and considerable number, 38 (31 percent) of the respondents disagreed with the statement. Statistical test done on this variable indicates that $(\mathrm{x} 2=.595 ; \mathrm{DF}=.01636 ; \mathrm{p}=.000)$.

Table 8:

\begin{tabular}{|c|c|c|c|c|c|c|c|c|c|}
\hline \multirow{3}{*}{$\begin{array}{l}\text { Research area } \\
\text { State resources } \\
\text { for rural } \\
\text { industrialization } \\
\text { development }\end{array}$} & & Agreed & Neutral & Disagree & $\mathbf{X}$ & & df & $\mathbf{P}$ & \\
\hline & $\begin{array}{l}\text { access } \\
\text { materials }\end{array}$ & $\begin{array}{l}58 \\
(46 \%)\end{array}$ & $\begin{array}{l}29 \\
(23 \%)\end{array}$ & $\begin{array}{l}38 \\
(31 \%)\end{array}$ & $\begin{array}{l}\mathrm{X} 2 \\
.595\end{array}$ & $=$ & $\begin{array}{l}\mathrm{df}= \\
1.01636\end{array}$ & $\begin{array}{l}\mathrm{P} \\
.000\end{array}$ & $=$ \\
\hline & $\begin{array}{l}\text { lack of sufficient } \\
\text { and } \\
\text { transportation }\end{array}$ & $\begin{array}{l}72 \\
(57 \%)\end{array}$ & $\begin{array}{l}25 \\
(20 \%)\end{array}$ & $\begin{array}{l}30 \\
(22 \%)\end{array}$ & $\begin{array}{l}X 2 \\
.666\end{array}$ & $=$ & $\mathrm{df}=1.19434$ & $\begin{array}{l}\mathrm{P} \\
.000\end{array}$ & $=$ \\
\hline
\end{tabular}

More than half 58(46 percent) of the respondents indicate access to the raw material as the main contributing factor into the rural industrialization, while 72(57 percent) mentioned lack of enough and quick transportation.

Table 9:

\begin{tabular}{llll}
\hline Tested Variables & $\mathbf{N}$ & P-Value & Correlation Coefficient \\
\hline Institutional barriers & 127 & .000 & $485^{* *}$ \\
Financial barriers & 127 & .000 & $421^{* *}$ \\
Social barriers & 127 & .000 & $388^{* *}$ \\
Network resources & 127 & .000 & $465^{* *}$ \\
\hline
\end{tabular}




\section{Conclusion}

Broad knowledge and understanding of factors affecting the use of modern technology for rural industrialization are vital for the national economy and economic social ills. Since the use of modern technology is tremendously increasing day-by-day in both social sectors and in the business circle in South Africa but this is not the case in many rural places. Rural communities and rural businesses operators, therefore, need to make to be familiar of and knowledgeable about what rural industrializations are; and what are the factors contributing to the use of modern technology for rural industrialization to promote economic activities and improve rural industry sector. Lack of proper knowledge strategy and understanding the use of modern technology and how it can benefit the process of rural industrialization Institutional barriers, financial barriers, social barriers and network resources contribute to the use of modern technology for rural industrialization in KZN.

Recommendations: Based on the empirical funding's of this survey, there are many challenges for rural industrialization everywhere in with specific reference to the emerging economics countries such as South Africa that need attention. This survey recommends that national governments need to put more resources for rural business development. All stakeholders should be encouraged to invest in technology upgrading for rural economic development and industrialization. The study recommends that government national policy for business should allow easy transactions for rural industrialization. The study also recommends business training and development programs should be introduced and encouraged among the rural communities.

\section{References}

AL-Mubaraki1, H. \& Aruna, M. (2013). Technology Innovation for SME Growth: A Perception for the Emerging Economies. Journal of Economics and Sustainable Development, 4(3).

Bar-El, R. \& Felsenstein, D. (1990). Entrepreneurship and rural industrialization: Comparing urban and rural patterns of locational choice in Israel, 18(2), 257-267.

Chapter - I, Rural Industrialization in India. (2017).

Dinkelman, T. (2010). The Effects of Rural Electrification on Employment: New Evidence from South Africa

Dhar, P. L. (2017). Rural industrialization- the future of technology.

Gandhi, V. P. (2014). Growth and Transformation of the Agribusiness Sector: Drivers, Models and Challenges. INDIAN Journal of agricultural economics, 69(1).

Ramey, K. (2012). Modern Technology Advantages and Disadvantages.

Report on Science \& technology for Small \& Medium Scale Enterprises (SMEs). (2017).

Michael, D., Aggarwal, N., Kennedy, D., Wenstrup, J., Rüßmann, M., Ruba, B., Chen, J. \& Bezerra, J. (2013). Lessons on Technology and Growth.

Kumar, S. (2017). Rural Development through Rural Industrialization: Exploring the Chinese Experience.

Hartley, K. (2015). Ural industrialization: Asia's 21st-century growth frontier.

Rai, N. \& Kumar, V. (2012). Role of science and technology in making rural India shine. IJRDMS, 6(1).

Warikandwa, C. (2018). Rural industrialization key to economic development.

Mpofu, K. C. \& Watkins-Mathys, L. (2011). Understanding ICT adoption in the small firm sector in Southern Africa, Journal of Systems and Information Technology, 13(2), 179-199.

Nkosana, T., Skinner, J. \& Goodier, C. (2016). Challenges of ICT adoption and utilization in small rural restaurants: a case study of the KwaZulu-Natal Midlands. African Journal of Hospitality, Tourism and Leisure, 5(4).

Hualou Long, H., Zou, J. \& Liu, Y. (2009). Differentiation of rural development driven by industrialization and urbanization in eastern coastal China, Habitat International, 33, 454-462

Shahabi, S., Salehi, A. \& Seifolahi, M. (2015). Investigation of the Factors Influencing the success of Rural Industries in Employment Generation (Case Study: Isfahan Province). Journal of Research and Rural Planning, 4(1), 9.

Lele, U. (2017). How technology is transforming the lives of India's farmers. The economic weekly, 1960). Rural Industrialization Its Pattern and Problems M C S, August 27, 1960

Vassilakopoulou, A. M. (2013). The contribution of technology in business growth: the case of Greek ladies, Journal of Innovation and Entrepreneurship.

Vitez, O. (2017). The Impact of Technological Change on Business Activity. 


\section{Journal of Economics and Behavioral Studies (ISSN: 2220-6140)}

Vol. 10, No. 6A, pp. 64-71, 2018

Manimala, M. J. \& Vijay, D. Technology Business Incubators (TBIs): A Perspective for the Emerging Economies. (2012).

Werngren, P. (2013). SMEs need to embrace technology to boost growth.

Jayadatta, S. (2017). Major Challenges and Problems of Rural Entrepreneurship in India. IOSR Journal of Business and Management (IOSR-JBM), 19(9), 35-44.

Patel1, B. \& Chavda, K. (2013). Rural Entrepreneurship in India: Challenge and Problems, International Journal of Advanced Research in Computer Science and Management Studies, 1(2).

Saxena, S. (2012). Problems Faced by Rural Entrepreneurs and Remedies to Solve It. IOSR Journal of Business and Management (IOSRJBM), 3(1), 23-29.

Sehgal, R. (2015). Essay on Importance of Industrialization.

Sundar and Srinivasan. (2009). Rural Industrialization: challenge and Proposition, Journal of social science, 20(1), 23-29.

Mwalenga, R. (2012). https://www.kenyaplex.com/resources/3570-the-importance-of-industrialisation-indevelopment.aspx (19/03/2018).

Khan, M. (2009). Industrialization and its importance to the economic development of Pakistan.

Schilling, M. \& Chiang, L. (2009). The Depletion of Non-renewable Resources for Non-Sustainable Externalities as an Economic Development Policy. 